\title{
Examining the Perception of the Order versus Freedom Dilemma in University Management ${ }^{\mathrm{i}}$
}

\author{
Figen Karaferye ${ }^{1, *}$, Esmahan Ağaoğlu ${ }^{2}$ \\ ${ }^{1}$ School of Foreign Languages, Dumlupinar University, Turkey \\ ${ }^{2}$ Graduate School of Educational Sciences, Anadolu University, Turkey
}

Copyright $\bigcirc 2017$ by authors, all rights reserved. Authors agree that this article remains permanently open access under the terms of the Creative Commons Attribution License 4.0 International License

\begin{abstract}
This study aims to analyze how the middle management at university handle with the order versus freedom dilemma - bureaucratic discipline, professional expertise; coordination, communication; managerial planning and individual initiative by giving a university case. A survey was applied on two different sample groups. 607 middle managers and academicians working in six different faculties and two schools in a HEI in 2014-2015 educational year compose the population of the study. Data for the study were gathered with the "Order vs. Freedom Dilemma Scale" and with semi-structured interview form "Opinions on the Order vs. Freedom Dilemma" both developed by the researcher. The findings of the study show that the choice of middle managers on order vs freedom dilemma is mostly for order. The choice of sub-dimensions related to order and/or freedom is important and each of those sub-dimensions need continuous development. Furthermore, it is suggested that individual orientations, professional norms, ideals and professional discipline all together with the institutional structure can be improved correspondingly and become more effective in practice. Besides, supporting the staff to reach each other in a better and closer communication space is also suggested by starting an interactive, effective and sustainable communication mechanism on middle and lower levels.
\end{abstract}

Keywords University Management, Dilemma, Middle Management, Order, Freedom

\section{Introduction}

Higher education is a multi-purpose system with its loosely-coupling mechanisms; control of the upper level over the lower levels; a great deal of differentiation; strong influence of professionals/academics on determining the objectives, management and daily-basis routines [22]. University managers/leaders in this system face many challenges especially in today's competitive and unstable setting. 'Evolving demands from superiors, financial challenges, faculty, and students create a turbulent environment in which administrators must thrive'. It appears university managers/leaders can cope effectively with these challenges. However, as those managers are faculty members assigned to the managerial position without formal preparation, they need to develop their managerial skills on the job [36].

Research shows that management and leadership influence the teaching environment. In this aspect, the perception of faculty towards the academic environment has a significant role. In their research, Wright and O'Neil [56] conducted a survey on people responsible for teaching improvement activities (academics, managers and other teaching improvement staff) in Canada, the USA, the UK and Australia over 300 campuses in 1992-1993. In the survey, participants were asked to rate the items from the most effective to the least in terms of their effect on teaching in their university. Results showed that the item 'leadership of deans and heads' (middle management) was rated as the most effective in all countries except Canada where it was rated as the second.

\subsection{Managing Academics}

Leadership and management notions are defined and interpreted in many ways, but simply, they are about power, impact between people, uniting strength and working to achieve organisational goals. Leaders and managers endeavour to motivate their staff by applying many methods such as guidance, authorisation, facilitation, coaching and mentorship [2, 8, 47]. However, these methods may differ regarding personal manners, competence, resources and organisational culture. Deans and department heads, as the middle management applying these approaches between the top management and working level, have a strategically important position in university management. While they are supplying information to the top management, they convey information to the academics and guide them 
accordingly. Being a middle manager is stressful because multiplicity of expectations and demands can cause confusion and conflicts, particularly at universities. As the base/working level is composed of professionals, those problems occur frequently [5].

Academics are the professionals working on the base level with a high level of intrinsic motivation. That is why their management is difficult. Since they are professionals, they may not be eager to be guided by a 'line manager' or see the organisational goals as top priority [7]. Furthermore, naturally people in organisations have different values and beliefs, few of them are shared. 'Depending on their role, functions, beliefs, needs and perceptions, and on their social and personal lives outside school', their interests differ. In order to achieve their agendas, depending on the authority/power they have access to, they use different strategies [11]. Hence, differences can be seen among academics about their sense of duty and attitude toward the organisation. At this point, middle managers responsible with the organisation of teaching activities work on bringing academics to a common vision to be able to achieve organisational goals during which dilemmas occur frequently.

\subsubsection{Organisational Dilemmas}

A dilemma is the paradox of two opposing ideas [45]. Those obviously conradictory two ideas are dealt with together. 'The value to be derived from paradoxical thinking stems from this duality' [49]. Hoy and Miskel [35] puts forth that the dilemma of order versus freedom is seen in formal organisations frequently. Both order and freedom are necessary and desirable for effectiveness. However, when one side increases, the other one decreases. Order vs freedom dilemmas seen in academic organisations in managerial practice are 'coordination vs communication; bureaucratic discipline vs professional expertise and managerial planning vs individual initiative' [35]. There are various studies on organisational dilemmas seen in managerial processes and how they can be managed in the university context $[27,28$, $39,58]$. They all put forth a manager should have in mind that dilemmas are always there in management to be handled with [13].

In Hoy and Miskel's work, organisational dilemmas show the tension between the standing pillars of an organisationcoordination \& communication; bureaucratic discipline \& professional expertise and managerial planning \& individual initiative in organizational management. Coordination is the process of combining people, materials and other resources in order to achieve organisational goals [51]. Moreover, as a means to achieve organisational goals, coordination provides adaptation in hierarchical structure. In the process of coordinating, communication is essential [37]. However, with the effect of differentiation and centralised management as the other essential elements, communication can be limited. In other words, within coordination, hierarchical differentiation and ranks can slow down decision-making and also limited communication can weaken effectiveness in problem-solving [35]. Communication, 'as the lifeblood of every school organisation' is the process of bonding the individual, the group and the organisation [41]. However, communication may have some disadvantages for the organisation since the free flow of information can prevent coordination although it improves problem-solving. With the gathering of many different views, negotiation can be difficult to be achieved and communication can cause setbacks whereas coordination can be seen as a safe and simple route with its agreement on a single-plan [35].

Universities as rational organisations function in an orderly manner with centralisation, hierarchical authority and formalising principles [26]. However, bureaucracy can carry some disadvantages for the organisation. For instance, with a strict division of labour practice, competition and novelties in a job can decrease. High commitment to bureaucratic rules can cause inefficiency, since after a while applying/obeying the rules can become top priority instead of achieving organisational goals. Moreover, they can cause red-tape. On the other hand, professional expertise requires specialised technical competence and compatibility to norms and ideals related to the academic field [55]. However, $\mathrm{H}$. Simon [48], states that bureaucratic authority and professional expertise contradict each other. They have a reciprocal relation, depending on the organisation type and goals, one side increases and the other decreases. Thus, problems can occur when a balance is not attained.

'Like a compass' managerial planning, as a future-oriented means provides guidance for action paths regarding organisational goals and taking precautions and while doing so, it is attentive to the economical and efficient usage of organisational resources [1, 9]. However, managerial planning requires centralisation and vertically structured hierarchy during which academics with information in lower ranks cannot communicate with managers in higher ranks sufficiently on decision-making and/or planning which can cause problems in organisation. On the other hand, individual initiative is about creativity, proactivity and novelty of the individual in the organisation apart from managerial planning. It also includes prompt actions towards problems. However, that means a contradiction with managerial planning. It carries a risk of failure as well as a chance of success, especially in organisational changes $[3,24]$.

In university management, it is essential to be aware of the essence of academic - organisational life which shows that order vs freedom dilemma - coordination vs communication; bureaucratic discipline vs professional expertise and managerial planning vs individual initiative as they are seen in academic organisations in managerial practice - are inevitable $[14,18,53]$. For this reason, an academic manager needs to work out the dilemma on an operational level by using one's managerial and leadership skills.

An academic manager with the responsibility of taking organisational goals as a prime concern, may have a 
tendency to apply order elements - bureaucratic discipline, managerial planning and coordination. In that way, he can make the definitions of roles, duties, functions and authority clear; underline rules and instructions; emphasise hierarchical structure and control. Yet, the academic staff is composed of professionals with competence in specific fields and working with professionals requires acting upon the norms and ideals related to the academic field. Moreover, culture, symbols and values need to be felt. Control processes need to embrace peer control and professional control [40]. Another thing is individual aspects and goals cannot be ignored. Therefore, an academic manager cannot ignore freedom elements - professional expertise, communication and individual initiative. Tensions can take place between those elements and the manager needs to manage the tension/dilemma.

\subsection{The Importance and Purpose of the Study}

The tendency in the dilemma management may give information about the structure of an organisation, its culture and habits. An academic manager responsible with managing the dilemma has his own evaluation and choice-right. The right side to choose in a dilemma situation depends on the analysis of the situation clearly, goals and needs of the organisation, differentiation and integration of academics and approach to conflict. Examining the perception of order versus freedom dilemma in university management and identifying which side of the dilemma is most often seen in practice can give information about the organisation to understand it better, it can raise awareness to the problems occurring as a result and it can help plan solution-oriented practices $[12,18]$. Examining the management of order vs freedom dilemma in practice in a university sample serves to be the first study in its field.

The purpose of this study is to analyse how the middle managers in a university handle the order versus freedom dilemma according to the perspectives of the middle managers and the academicians by asking these questions:

a) What is the perception of the academic staff towards the management of order vs freedom dilemma? Does the perception of the academics towards the management of order vs freedom dilemma show significant difference based on the variables: gender, age, work experience, academic title and work year in the same HEI (Higher Education Institution)?

b) How do middle managers appraise the management of order vs freedom dilemma in practice? For the purpose of the study, dilemma-situations are identified and the management of these dilemmas is discussed.

\section{Materials and Methods}

Mixed methods - The Explanatory Sequential Design which enables using quantitative and qualitative methods complementarily was used in the study. It provides in-depth analysis and detailing in the study [19]. This method, also called triangulation, brings different methods' strengths and weaknesses together to balance each other out. It also strengthens the findings when similar results reveal [44]. In the study, firstly a survey was conducted to the academics, then interviews are conducted both with the middle managers and the academics.

\subsection{Population and Sampling}

In the educational year 2014-2015, in six different faculties and two schools in a HEI, 607 middle managers and academicians composed the population of the study; 111 of 607 were middle managers and 496 were the academics in different schools/departments in the same campus of the HEI. In the quantitative part of the study, as it was aimed to make an in-depth analysis of the order vs freedom dilemma in a university case, no sampling technique was used in the survey and instead, it was aimed to reach all target population of the study. The survey was sent to 496 academics and in the end data from 235 participants were obtained to be analysed. In the qualitative part of the study, convenience sampling was used, in which 'the researcher selects participants because they are willing and available to be studied' $[19,57]$. This sampling technique is mostly preferred in qualitative research. Interviews were conducted face-to-face with participants in a semi-structured way. The participants consisted of 10 middle managers and 10 academics.

\subsection{Data Tools and Analysis}

Data tools in the study were developed by the researcher. In the survey, 'The Scale of Order vs Freedom Dilemma' was used; in the interviews 'The Opinions on Order vs Freedom Dilemma' was used. It was aimed to obtain the tendency of the middle management on the order vs freedom dilemma in their managerial practice in the department in academics' perspective. In order to see the frequency of the choice on the dilemma, statements were given with 5 Likert Type Scale changing between 1 (Never) and 5 (Always). The interview questions were designed to generate relevant data on the conflicts and dilemma situations in the department and the management of them. Both academics and middle management were interviewed.

In the analysis of the data obtained from academics with 'The Scale of Order vs Freedom Dilemma', frequency (n) and percentage (\%) analyses were done on academics' demographics; mean $(\bar{X})$ and standard deviation (sd) were calculated for the sub-dimensions (coordination vs communication; bureaucratic discipline vs professional expertise and managerial planning vs individual initiative) of the scale to examine the rating. After normality tests of Kolmogorov-Smirnov and examining histograms, parametric tests - t-test, one-way ANOVA and post-hocs 
were done. In the analysis of the qualitative data, interview recordings were transcribed, categorised and reviewed by using the content analysis technique. This technique enables a detailed contextualised interpretation by examining the frequency of words/phrases in interviews/texts and categorizing them to interpret $[21,57]$.

\section{Results and Discussion}

The results of the study show that a) in order vs freedom management, academics perceive the managerial planning vs individual initiative sub-dimension as being stronger than the other sub-dimensions -coordination vs communication and bureaucratic discipline vs professional expertise. Moreover, in managerial planning vs individual initiative dilemma management, managerial planning as an order element is perceived by academics as being chosen more by the middle management.

It is seen that in the practice of middle management, academics' perceptions regarding gender and age do not differ significantly. Based on gender and age, academics in all categories think members of the middle management in their department have a tendency toward communication in the coordination vs communication dilemma. About bureaucratic discipline vs professional expertise and managerial planning vs individual initiative dilemmas, they think the middle managers have a balanced/transitive understanding of practice. However, when those two sub-dimensions are compared, it is seen that managerial planning as an order element is perceived as being stronger than the other elements. There are statistically significant differences obtained in the analyses of the other demographics -work experience, academic title and work year in the same HEI. It can be summarised as; middle managers have a leaning towards the order elements and it is important to see which of these elements are perceived by academics as being chosen more by the middle management.

Qualitative data findings can be summarised as; in academics' perceptions in their departments conflicts occur as a consequence of the differences underlying beneath, such as individual, title and professional expertise - field differences. Particularly, when it comes to the distribution of roles/courses/tasks, with the effect of determinants as the number of academics and students, professional expertise-fields and academics' differences among each other in individual expectations and so on, conflicts frequently arise. Additionally, as there may be communication-based problems among staff such as polarisations and groupings, conflict management gets heavier. At this point, the middle management proceeds with the order elements more even though they do not ignore the freedom elements.

The results of the study show that b) middle managers believe that they have to prioritise order elements in many circumstances due to various determinants such as the number of academics and students, physical structure, the number and competence of administrative staff, hierarchical structure of academic titles, courses and their weekly schedules. Furthermore, it is seen that communication, professional expertise and individual initiative as freedom elements are not ignored, depending on the circumstance/topic, academics are motivated to participate in managerial processes as much as possible. However, they may have different attitudes from each other. Middle managers believe that in formal tasks' management, they experience time management problems, division of work problems, occasionally problems about lack of knowledge/experience (both in middle management and academics), role ambiguities and shirking of responsibilities. It is seen that both order and freedom elements need to be improved on an operational level, yet, as a result of work load and time management issues, middle managers tend to do the work without causing delays, in other words, administrative duties come first before leadership skills and practice.

Findings on quantitative data and findings on qualitative data are given respectively in detail below.

\subsection{Quantitative Data Findings}

Mean values of the sub-dimensions obtained from the scale analyses are calculated as it is seen in Table 1 .

Table 1. n, $\bar{X}$ and sd Values of the Sub-dimensions in Order vs Freedom Dilemma Scale

\begin{tabular}{|c|c|c|c|}
\hline Sub-dimensions & $\mathrm{n}$ & $\overline{\boldsymbol{X}}$ & $\mathrm{sd}$ \\
\hline Coordination-Communication & 235 & 2,68 & 1,38 \\
\hline $\begin{array}{c}\text { Bureaucratic discipline-Professional } \\
\text { expertise }\end{array}$ & 235 & 2,99 & 1,06 \\
\hline $\begin{array}{c}\text { Managerial planning-Individual } \\
\text { initiative }\end{array}$ & 235 & 3,57 & 1,02 \\
\hline
\end{tabular}

It is seen that academics perceive coordination vs communication and bureaucratic discipline vs professional expertise dimensions as being close in value whereas managerial planning vs individual initiative is perceived as being highly significant $(\bar{X}=3,57)$. With the formula of number of intervals/number of items $(4 / 5=0,8)$, this value shows that managerial planning as an order element is perceived as being stronger $(3,4 \leq 3,57<4,19)$ than individual initiative.

Regarding the demographics gender and age, there is no significant statistical difference. Similar research results were obtained in Korkut's [38] study on the behaviour of middle managers in HEIs. There was no difference regarding gender. The result can be explained with the effect of bureaucratic roles and expectations. Different comments regarding gender were obtained concerning communication problems arising in the interaction of academics or in academic competititon of the same gender.

Regarding work experience, academic title and work year in the same HEI demographics, significant statistical difference and its difference groups are given below. Regarding work experience, there is significant difference in 
the management of bureaucratic discipline vs professional expertise as it is seen in Table 2. The difference is seen between the academics with the work experience of $0-5$ years and 6-10 years; 6-10 years and 16 years and above. When the cause of the difference is examined, it is seen that academics with the work experience of 6-10 years perceive bureaucratic discipline as being highly significant.

In the research made on novice teachers it is suggested that teachers/academics tend towards bureaucratic elements rather than professional expertise [35]. They work depending on the centralised and hierarchical structure. Acting in the command of rules and regulations has a strong effect. As obtained in the qualitative data, academics do not yet have a sufficient understanding of formal procedures, organisational culture and professional norms in the beginning. Hence, in some departments the positive effect of mentorship is emphasised which makes a difference. Knowledge of bureaucratic procedures, rules \& regulations and professional expertise-based knowledge grow in time as experience grows in institutional culture. Effective mentorship processes provide academics with many advantages as academical, social and formal support, adaptation to the institutional culture, motivation and fulfilling responsibilities without setbacks [2, 25, 34]. As there are differences of mentorship availability among departments, further studies can be conducted.

Regarding academic title, there is significant difference in the management of coordination vs communication as it is seen in Table 3. In academic titles, group 1 is composed of instructors; group 2 is composed of research assistants; group 3 is composed of lecturers; group 4 is composed of professors and associate/assistant professors. When the cause of the difference is examined, it is seen that the significant difference is between research assistants and professors. It is seen that research assistants perceive the implementation of coordination higher than communication in coordination vs communication dilemma management.

The qualitative data also indicated that formal/bureaucratic tasks in a department/school are shared among research assistants by the management. Here it is important to consider research assistants' roles/functions, competency, availability and to assign sufficient time [35, $51,52]$. Depending on the number of research assistants and the size of the department, in some departments the prioritisation of coordination over communication is inevitable even though it is not desired.

In managerial planning vs individual initiative dimension, significant difference is seen between those with different academic titles specifically research assistants and lecturers; lecturers and professors as it is seen in Table 4.

Table 2. Bureaucratic Discipline-Professional Expertise Dimension ANOVA Test Results of Work Experience

\begin{tabular}{|c|c|c|c|c|c|c|c|c|}
\hline Dimension & Groups & $\mathrm{n}$ & $\bar{X}$ & sd & df & $\mathrm{F}$ & $\mathrm{p}$ & Difference groups \\
\hline \multirow{4}{*}{$\begin{array}{l}\text { Bureaucratic discipline-Professional } \\
\text { expertise }\end{array}$} & 1 & 73 & 2,83 & ,68 & \multirow{4}{*}{$3-231$} & \multirow{4}{*}{4,406} & \multirow{4}{*}{, 005} & \multirow{4}{*}{$\begin{array}{l}1-2 \\
2-4\end{array}$} \\
\hline & 2 & 56 & 3,18 & ,69 & & & & \\
\hline & 3 & 51 & 2,87 &, 59 & & & & \\
\hline & 4 & 55 & 2,76 & ,67 & & & & \\
\hline
\end{tabular}

Table 3. Coordination-Communication Dimension ANOVA Test Results of Academic Title

\begin{tabular}{|c|c|c|c|c|c|c|c|c|}
\hline Dimension & Groups & $\mathrm{n}$ & $\bar{X}$ & sd & df & $\mathrm{F}$ & $\mathrm{p}$ & Difference groups \\
\hline \multirow{4}{*}{ Coordination-Communication } & 1 & 44 & 2,41 & ,35 & \multirow{4}{*}{$3-231$} & \multirow{4}{*}{3,526} & \multirow{4}{*}{.016} & \multirow{4}{*}{$2-4$} \\
\hline & 2 & 74 & 2,43 & ,38 & & & & \\
\hline & 3 & 38 & 2,33 & ,33 & & & & \\
\hline & 4 & 79 & 2,24 & ,43 & & & & \\
\hline \multicolumn{9}{|c|}{ Groups: 1: Ins.; 2: Res.Ass.; 3: Lec.; 4: Prof. } \\
\hline
\end{tabular}

Table 4. Managerial Planning-Individual Initiative Dimension ANOVA Test Results of Academic Title

\begin{tabular}{|c|c|c|c|c|c|c|c|c|}
\hline Dimension & Groups & $\mathrm{n}$ & $\bar{X}$ & $\mathrm{sd}$ & $\mathrm{df}$ & $\mathrm{F}$ & $\mathrm{p}$ & $\begin{array}{c}\text { Difference } \\
\text { groups }\end{array}$ \\
\hline \multirow{4}{*}{$\begin{array}{c}\text { Managerial } \\
\text { planning-Individual } \\
\text { initiative }\end{array}$} & 1 & 44 & 3,39 & ,64 & \multirow{4}{*}{$3-231$} & \multirow{4}{*}{4,414} & \multirow{4}{*}{, 005} & \multirow{4}{*}{$\begin{array}{l}2-3 \\
3-4\end{array}$} \\
\hline & 2 & 74 & 3,30 & ,65 & & & & \\
\hline & 3 & 38 & 3,64 &, 59 & & & & \\
\hline & 4 & 79 & 3,22 & ,49 & & & & \\
\hline \multicolumn{9}{|c|}{ Groups: 1: Ins.; 2: Res.Ass.; 3: Lec.; 4: Prof. } \\
\hline
\end{tabular}


When the cause of the difference is examined, it is seen that lecturers perceive managerial planning as an order element stronger than individual initiative in managerial planning vs individual initiative management. This result can be associated with the article/regulations that lecturers are assigned to departments for certain periods of time to run courses. Generally in those different departments where they are temporarily assigned, they are not expected to participate in departmental meetings but merely obey the managerial outcomes/norms. This situation can be shown as a reason for their perception of a tight-coupling structure being dominant [54]. To gain strength in the institutional culture and raise commitment to goals/norms, managerial planning vs individual initiative need to be balanced. For instance, by practising 'participatory decision-making' processes, more academics can be involved [35].

Regarding working in the same HEI, there is significant difference in the management of coordination vs communication as it is seen in Table 5. There is significant difference between the academics working in the same HEI for $0-5$ years and 11-15 years; between 6-10 years and 11-15 years. When the cause of the difference is calculated in posthoc tests, it is seen that the academics working in the same HEI for 0-5 years and 6-10 years perceive coordination as being implemented more than communication. As working experience in the HEI increases, the two sides of the dimension become more transitive.

It is also obtained from qualitative data that as working experience in the same HEI increases, academic and social relations become complementary; organisational culture gains strength with academic-academic and management-academic effective communication processes. In the beginning years of working experience, there is no sufficient acquisition of shared-values and culture [32, 52].

In bureaucratic discipline vs professional expertise dimension, there is significant difference regarding working in the same HEI as seen in Table 6.

There is significant difference between the groups of 6-10 years and 11-15 years. When the cause of the difference is calculated in posthoc tests, it is seen that the academics working in the same HEI for 6-10 years perceive bureaucratic discipline as being implemented more. This finding can be explained with the fact that teachers/academics approach the organisation in a formal/bureaucratic way as they do not have any shared-beliefs and values of the organisation yet. The critical thing here is not to habitually put formal/bureaucratic processes before professional ideals and norms [17]. As the work experience in the same HEI increases, the effect of institutional culture, acting upon professional/peer control and professional group monitoring in the institution increase and a tension between bureaucratic discipline and professional expertise start [35]. Some studies $[15,43]$ about this subject suggest with the increase in working experience, professional expertise and autonomy, bureaucratic orientations and professionalism would not contradict.

In managerial planning vs individual initiative dimension, there is significant difference regarding working in the same HEI as it is seen in Table 7.

Table 5. Coordination-Communication Dimension ANOVA Test Results of Working in the Same HEI

\begin{tabular}{|c|c|c|c|c|c|c|c|c|}
\hline Dimension & Groups & $\mathrm{n}$ & $\bar{X}$ & sd & df & $\mathrm{F}$ & $\mathrm{p}$ & Difference groups \\
\hline \multirow{4}{*}{ Coordination-Communication } & 1 & 98 & 2,36 & ,35 & \multirow{4}{*}{$3-231$} & \multirow{4}{*}{4,569} & \multirow{4}{*}{, 004} & \multirow{4}{*}{$\begin{array}{l}1-3 \\
2-3\end{array}$} \\
\hline & 2 & 60 & 2,45 & ,39 & & & & \\
\hline & 3 & 39 & 2,15 &, 34 & & & & \\
\hline & 4 & 38 & 2,35 & ,48 & & & & \\
\hline \multicolumn{9}{|c|}{ Groups: $1: 0-5$ years; $2: 6-10$ years; $3: 11-15$ years; $4: 16$ years and above } \\
\hline
\end{tabular}

Table 6. Bureaucratic Discipline-Professional Expertise Dimension ANOVA Test Results of Working in the Same HEI

\begin{tabular}{|c|c|c|c|c|c|c|c|c|}
\hline Dimension & Groups & $\mathrm{n}$ & $\overline{\boldsymbol{X}}$ & $\mathrm{sd}$ & $\mathrm{df}$ & $\mathrm{F}$ & $\mathrm{p}$ & Difference groups \\
\hline \multirow{8}{*}{$\begin{array}{c}\text { Bureaucratic } \\
\text { discipline-Professional } \\
\text { expertise }\end{array}$} & 1 & 98 & 2,86 &, 64 & & & \\
\cline { 2 - 6 } & 2 & 60 & 3,10 &, 71 & \multirow{2}{*}{$3-231$} & 2,717 & \multirow{2}{*}{045} & $2-3$ \\
\cline { 2 - 6 } & 3 & 39 & 2,73 &, 70 & & & \\
\hline
\end{tabular}

Table 7. Managerial Planning-Individual Initiative Dimension ANOVA Test Results of Working in the Same HEI

\begin{tabular}{|c|c|c|c|c|c|c|c|c|}
\hline Dimension & Groups & $\mathrm{n}$ & $\bar{X}$ & sd & $\mathrm{df}$ & $\mathrm{F}$ & $\mathrm{p}$ & $\begin{array}{c}\text { Difference } \\
\text { groups }\end{array}$ \\
\hline \multirow{4}{*}{$\begin{array}{c}\text { Managerial } \\
\text { planning-Individual } \\
\text { initiative }\end{array}$} & 1 & 98 & 3,47 & ,65 & \multirow{4}{*}{$3-231$} & \multirow{4}{*}{3,148} & \multirow{4}{*}{, 026} & \multirow{4}{*}{$1-4$} \\
\hline & 2 & 60 & 3,32 & 60 & & & & \\
\hline & 3 & 39 & 3,26 & ,49 & & & & \\
\hline & 4 & 38 & 3,15 &, 50 & & & & \\
\hline
\end{tabular}


There is significant difference between the groups of 0-5 years and 16 years and above. When the cause of the difference is calculated in posthoc tests, it is seen that the academics working in the same HEI for $0-5$ years perceive managerial planning as being stronger. Academics in their beginning years generally concentrate on learning the stages of planned procedures and what to do accordingly [4]. Hence, planning with centralised understanding, communication in vertical hierarchy and control become distinguishable [9]. With the consolidation of institution specific and professional field-based norms, codes of behaviour and ideals; with the growth of trust in shared-beliefs, managerial planning and individual initiative are balanced [14]. In that way, an individual is empowered in the organisation, too [4].

\subsection{Qualitative Data Findings}

In the analysis of qualitative data, themes and sub-themes are obtained from the views of the middle management and academics as in Table 8. Through themes and sub-themes, problems and conflicts that the middle management faces in practice and the dilemmas of solving them are discussed. Views of both the middle management and academics have been gathered below the same themes, yet, sub-themes have some differences.

Regarding the 'division of labour' theme; views gather below the sub-themes; the number of academics, distribution of courses, proctor assignments and other works such as internship files, etc. 'The number of academics' sub-theme is obtained from the middle management's views. Dilemma situations occur in those topics mentioned and in the management of the dilemmas; time management, the number of the staff and work-sharing in rotation are emphasised. Additionally, it is seen that transparency in division of labour sets a positive tone in the organisation.

Everything within an organisation starts with the division of labour, and the tone of the organisation about this affects the attitude of the academics determining whether or not they are eager to take responsibility of more tasks and duties. Since an academic fulfills scheduled tasks and duties, invests in his professional expertise and manages academic competition, time management is critical. Hence, middle managers need to consider all those elements and plan the division of labour, make use of active and effective communication and lead transparent management accordingly. That way, dilemmas in division of labour management, mostly tending to order elements, would be balanced with the use of freedom elements.

Regarding the 'communication' theme; views gather under the sub-themes; problems in communication, formal communication channels and academic \& social communication. In those sub-themes, physical structure, size of the organisation, adaptation, academic competition, academic loneliness, staying silent, individual differences in communication, variety of communication channels/tools, taking transparency and accountability principles into consideration both by the middle management and academics, personal relations and polarisations \& groupings topics are emphasised. Having groups and sub-groups in organisations is common, however connecting those to each other/other individuals/the management and gathering them on a shared vision requires effective communication processes which are managed by the middle managers [10, $11,23]$. It is seen that there are problems stated such as not communicating in a desired way because of barriers and bias. Therefore, effective communication techniques and processes can be varied in formal and informal platforms to be able to create more communicative opportunities. In Olcer and Kocer's [46] research on organisational communication, as a similar finding it is suggested that communication setbacks and problems are very common among academics and effective solutions need to be found.

Table 8. Themes and Sub-themes Based on the Views

\begin{tabular}{|c|c|c|c|c|}
\hline Themes & $\begin{array}{l}\text { Sub-themes Based on Middle } \\
\text { Management's Views }\end{array}$ & $\mathrm{f}$ & Sub-themes Based on Academics' Views & $\mathrm{f}$ \\
\hline 1. Division of labour & $\begin{array}{l}\text { 1. The number of academics } \\
\text { 2. Distribution of courses } \\
\text { 3. Proctor assignments } \\
\text { 4. Other (internship files, etc) }\end{array}$ & $\begin{array}{l}6 \\
9 \\
9 \\
9\end{array}$ & $\begin{array}{l}\text { 1. Distribution of courses } \\
\text { 2. Proctor assignments } \\
\text { 3. Other (internship files, etc) }\end{array}$ & $\begin{array}{c}10 \\
9 \\
9\end{array}$ \\
\hline 2. Communication & $\begin{array}{l}\text { 1. Problems in communication } \\
\text { 2. Formal communication channels } \\
\text { 3. Academic and social communication }\end{array}$ & $\begin{array}{l}7 \\
9 \\
8 \\
\end{array}$ & $\begin{array}{l}\text { 1. Problems in communication } \\
\text { 2. Formal communication channels } \\
\text { 3. Academic and social communication }\end{array}$ & $\begin{array}{c}9 \\
10 \\
9\end{array}$ \\
\hline $\begin{array}{l}\text { 3. Formal / } \\
\text { Bureaucratic tasks }\end{array}$ & $\begin{array}{l}\text { 1. Management of formal tasks } \\
\text { 2.The electronic document management } \\
\text { system }\end{array}$ & 9 & $\begin{array}{l}\text { 1. Sharing the tasks with academics and } \\
\text { administrative staff } \\
\text { 2. Managerial position }\end{array}$ & 7 \\
\hline $\begin{array}{l}\text { 4. Plans of the management and } \\
\text { expectations of academics }\end{array}$ & $\begin{array}{l}\text { 1. Viewpoints } \\
\text { 2. Communication } \\
\text { 3.Institutionalisation }\end{array}$ & $\begin{array}{l}7 \\
6 \\
6\end{array}$ & $\begin{array}{l}\text { 1. Differentiation in expectations } \\
\text { 2. Asking for opinions } \\
\text { 3. Allowances } \\
\text { 4.Institutionalisation }\end{array}$ & $\begin{array}{c}10 \\
6 \\
5 \\
10\end{array}$ \\
\hline 5. Taking responsibilities & $\begin{array}{l}\text { 1. Well-balanced sharing } \\
\text { 2. Incentives } \\
\text { 3. Bias }\end{array}$ & $\begin{array}{l}7 \\
6 \\
9\end{array}$ & $\begin{array}{l}\text { 1. Well-balanced sharing } \\
\text { 2. Incentives } \\
\text { 3. Making contributions }\end{array}$ & $\begin{array}{c}6 \\
8 \\
10\end{array}$ \\
\hline
\end{tabular}


Moreover, it is indicated that the tendency toward communication is high. Principles and standards of communication processes need to be set, available and practical, which means order elements are needed to support communication processes. Both in the management's and academics' views, academics who are difficult to work and communicate with are mentioned. Here, bureaucratic discipline and professional expertise together with coordination \& communication can be integrated to strengthen the sense of duty \& belonging and motivation of those academics. It is seen that lack of experience/knowledge, academic competition, weak usage of communication techniques and fear $\&$ bias about the task/responsibility have an impact on the academic's choice of being silent/passive. Those issues cannot solely be managed with formal routines, yet professional expertise and communication elements need to be strengthened in the process.

Regarding the 'formal/bureaucratic tasks' theme; views of the middle management gather under the sub-themes; management of formal tasks and the electronic document management system. Views of the academics gather under the sub-themes; sharing the tasks with academics and administrative staff and managerial position. In the middle management's views, formal/bureaucratic tasks must be done, however, when they become the sole work, problems start. Well-balanced work-sharing in rotation plans made by the middle managers help in dilemma management, which means a tendency towards order. Furthermore, lack of knowledge/experience among academics/newly appointed managers may create problems. The electronic document management system provides mobility and practicality, but again it needs the middle management to spend time on formal/bureaucratic tasks. Additionally, in academics' views, formal/bureaucratic tasks are mostly done by the middle management, administrative staff and research assistants if there is a sufficient number of them. Also, some of the academics do the tasks in return. Hence, the work load is only on those who carry the work. It is also seen that while some academics refer to formal/bureaucratic tasks as heavy and time-consuming, some (who do not have a coordinator role or any other type of managerial position) think there is no such issue. Therefore, it can be interpreted that academics have different perceptions of what formal/bureaucratic tasks are and how they are run.

Regarding the 'plans of the management and expectations of academics' theme; views of the middle management gather under the sub-themes, viewpoints, communication and institutionalisation. Views of the academics gather under the sub-themes; differentiation in expectations, asking for opinions, allowances and institutionalisation. The 'allowances' sub-theme is only in the views of academics. It is seen that the middle managers have a tendency to come to an evaluation considering multiple aspects. However, academics, naturally, have their own/individual aspects of evaluation which can create conflicts based on different viewpoints. It is also stated in literature that academics are not homogeneous, but heterogeneous [29]. As efficient outcomes for the organisation/institution are desired primarily, multiple \& different views/requests are met as much as circumstances allow. Rational plans are made based on the mixture of formal/bureaucratic factors, participation of academics and mutual interactions $[6,14,50]$.

On the negotiation of management plans and academics' expectations; transparency, accountability, mutual decision-making, the number of academics, communication channels, adaptation and organisational culture have impacts. In the views it is seen that, differences in academics' individual expectations affect both management plans and other academics in the department. Hence, it is important that the middle management makes use of institutional structure and communication processes together effectively and also integrate institutional rules and principles with organisational culture values in the management of managerial planning vs individual initiative. Thus, it is possible to say that middle managers fulfill a difficult mission in meeting both ends $[5,20]$.

Regarding the 'taking responsibilities' theme; views of the middle management gather under the sub-themes; well-balanced sharing, incentives and bias. Views of the academics gather under the sub-themes; well-balanced sharing, incentives and making contributions. The last sub-theme is different in the groups. It is obtained in these sub-themes that effective usage of communication techniques by the middle management and as tangible incentives are limited, motivating with notable intangibles are important in dilemma management. Also, mentorship and providing the academics with sufficient information to fulfill a task are important.

Moreover, constructive criticism in organisational culture, communication processes among academics themselves, the effect of individual attitudes towards whether making extra contributions to the rest of the organisation and time management plans for extra responsibilities play important roles in determining the tone of the organisation towards taking responsibilities. Particularly in academics' views, support \& contributions of the management and senior academics, trust to the work-sharing plans of the management and feeling of exhaustion topics are emphasised. It is seen that communication, professional expertise, coordination and managerial planning need to be integrated in order to get good results in taking responsibilities. In some departments order elements are not yet integrated with shared-values \& beliefs and individual initiative is not yet supported controllably. Furthermore, the informal side of communication is powerful and instead of an integrating effect it has a separatist effect. Thus, it can be interpreted that there is a need to recognise the sub-dimensions and effects of the order vs freedom dilemma thoroughly within an institution.

\section{Conclusions and Recommendations for Further Work}

In summary, order elements are dominant due to the 
factors such as the number of academics, administrative staff, students, physical structure, hierarchical structure of academic titles, courses and their scheduling in order vs freedom dilemma management. On the other hand, freedom elements - communication, professional expertise and individual initiative are not ignored, depending on the topic, academics are encouraged to be involved in managerial processes as much as possible. Yet, with the increase in the number of academics and differentiation in professional expertise and/or academic titles, communication problems and conflicts increase. Middle managers prioritise running the workflow without delays by the usage of coordination and managerial planning. In formal/bureaucratic tasks' management; problematic situations related to time management, work-sharing, sometimes lack of knowledge/experience, role ambiguities and shirking of responsibilities are mentioned. At this point, again middle managers solve problems in bureaucratic ways with managerial planning. Unfortunately, professional expertise and individual initiative may fall behind.

In university management, concerning communication problems (polarisations, weak negotiation, staying silent, not being transparent in formal meetings, etc) between management-academic and academic-academic, there is an effort to manage them by considering the institutional and professional identity and by varying communication techniques and processes. However, those require a great deal of time and effort, and unfortunately due to the other duties/tasks to be done, particularly administrative procedures, sometimes leadership processes can fall behind $[29,30]$. In academics' views, academics' impact on each other based on their individual differences (personally, academically or socially) can become effective on division of labour, taking responsibilities or in communication problems. Academics are in need of more academic and social platforms organised by the management to get closer to each other both academically and socially. Even though academics have a free flow of communication compared to the management, disconnections, polarisations \& groupings and academic competition are common. And this leads to isolation in academia/academic loneliness, especially by continually focusing only on academic work [16].

Furthermore, based on academics' views, there are different perceptions of order-related concepts such as transparency, accountability, definitions of roles \& duties and principles \& standards. Academic processes naturally require awareness of roles $\&$ duties $\&$ responsibilities both formally and professionally [33]. Thus, since institutionalism needs to be improved and recognised more, it can be suggested to the academic developers and educational practitioners that further research in the institution is needed to address the exact needs of the faculty. Interactive processes and continuous exchange of information could be designed through offline and online networks in the institution. Another important need obtained is professional expertise (professional norms and peer \& professional control, etc) and communication (a variety of communication channels \& techniques \& platforms) need to be strengthened. Further research by the academic developers and educational practitioners could lead a way toward field-specific or department-specific professional development programs in the institution enabling a stronger professional expertise mechanism with dynamic communication processes. It is also obtained that departments with mentoring processes experienced more effective processes of bureaucratic and professional information exchange. In addition, emergence of academic and social interactions among faculty is experienced more naturally and sustainably in those departments, which makes is vital that further research is needed to design effective and sustainable field/department-specific mentoring and peer-coaching programs in the institution. Lastly, concerning individual initiative it is seen that, particularly in career development and professional development, academics need more variety and options. Further research can be suggested toward obtaining more participatory and complementary processes by getting together the perspectives \& expectations of various stakeholders both in and out of the institution.

Further research is needed in academic organisations to improve individual orientations, professional norms, ideals and professional discipline all together with the institutional structure correspondingly to obtain more effective processes in practice. Moreover, further research on designing an interactive, effective and sustainable communication mechanism on middle and lower levels is suggested to support the staff in reaching each other through a better and closer communication platform. Further research on order vs freedom dilemma management by the researchers can too be done by studying HEIs in different categories regarding their foundational years; by studying a single department/school in different HEIs considering department/school specific features. Finally, the tension between order and freedom can be studied between the top management and the middle management levels since the managerial processes in those levels have their own unique structure.

\subsection{Limitations}

This research is limited to the views of the academics and managers working in six faculties and two schools in a HEI in the 2014-2015 educational year. Managers are limited to the middle managers (deans, vice-deans, directors, assistant directors, department heads and assistant department-heads). The management of order vs freedom dilemma can vary from university to university or even from unit/campus to unit/campus in the same university. For this reason, a study of a university sample (the central campus) in its own unique structure was examined in this research. 


\section{REFERENCES}

[1] Balc1, A. \& Pehlivan, İ. (2001). Eğitim yönetimi. Ankara: Ostim Mesleki Eğitim Merkezi.

[2] Balkar, B. \& Şahin, S. (2014). Aday öğretmenlere yönelik mentörlük programının uygulanmasına ilişkin eğitimcilerin görüssleri. The Journal of Academic Social Science Studies, 29, 83-100.

[3] Binnewies, C., Ohly, S. \& Sonnentag, S. (2007). Taking personal initiative and communicating about ideas: What is important for the creative process and for idea creativity?.European Journal of Work and Organizational Psychology, 16 (4), 432-455.

[4] Bitner, M.J., Booms, B.H. \& Tetreault, M.S. (1990). The service encounter: Diagnosing favorable and unfavorable incidents. Journal of Marketing, 54, 71-84.

[5] Boer, H.D., Goedegebuure, L. \& Meek, V.L. (2010). The changing nature of academic middle management: A framework for analysis. In V.L. Meek et al. (Eds.), The changing dynamics of higher education middle management (pp. 229-242). London: Springer.

[6] Bolman, L.G. \& Deal, T.E. (2008). Reframing organizations: Artistry, choice and leadership. San Francisco: Jossey-Bass Business and Management Series.

[7] Bolton, A. (2000). Managing the academic unit. Buckingham: Open University Press.

[8] Bowman, R.F. (2002). The real work of academic chair. The Clearing House: A Journal of Educational Strategies, Issues and Ideas, 75 (3), 158-162.

[9] Bursalığlu, Z. (2008). Okul yönetiminde yeni yapr ve davranış. Ankara: Pegem Akademi.

[10] Busher, H. \& Harris, A. (2004). Leadership of school subject areas: Tensions and dimensions in managing in the middle. In H. Tomlinson (Ed.), Educational management: Major themes in education Vol 3 (pp. 349-362). London: Routledge Falmer.

[11] Busher, H. (2006). Understanding educational leadership: people, power and culture. New York: Open University Press.

[12] Capano, G. \& Regini, M. (2014). Governance reforms and organizational dilemmas in European Universities. Comparative Education Review, 58 (1), 73-103.

[13] Cardno, C. (2007). Leadership learning - the praxis of dilemma management. International Studies in Educational Administration 35 (2), 33-50.

[14] Carnall, C. (2007). Managing change in organizations. London: Pearson Education.

[15] Chauvin, S.W. \& Ellett, C.D. (1993, November). Teachers' professional orientation: an empirical examination of the construct validity using the results of large-scale factor analyses. Paper presented at the annual meeting of the Mid-South Educational Research, New Orleans, LA.

[16] Churchman, D. \& King, S. (2009). Academic practice in transition: Hidden stories of academic identities, Teaching in Higher Education, 14 (5), 507-516.

[17] Clark, D.L. (1981). A sampler of alternative perspectives and models for viewing educational organizations. In D.L. Clark,
S. McKibbin \& M. Malkas (Eds.), Alternative Perspectives for Viewing Educational Organizations (pp. 31-45). San Francisco: Far West Laboratory for Educational Research and Development.

[18] Collinson, D. (2014). Dichotomies, dialectics and dilemmas: New directions for critical leadership studies?. Leadership, 10 (1), 36-55

[19] Creswell, J.W. (2012). Educational research: Planning, conducting and evaluating quantitative and qualitative research. Boston: Pearson.

[20] Decramer, A., Smolders, C. \& Vanderstraeten, A. (2013). Employee performance management culture and system features in higher education: Relationship with employee performance management satisfaction. The International Journal of Human Resource Management, 24 (2), 352-371.

[21] Elo, S. \& Kyngas, H. (2008). The qualitative content analysis process. Journal of Advanced Nursing, 62 (1), 107-115.

[22] Enders, J. (2007). The academic profession. In J.J.F.Forest \& P.G.Altbach (Eds.), International handbook of higher education: Part 1. Global themes and contemporary challenges (pp. 5-21). Dordrecht: Springer.

[23] Eren, E. (2008). Örgütsel davranış ve yönetim psikolojisi. İstanbul: Beta Yayınları.

[24] Fay, D. \& Frese, M. (2000). Self-starting behaviour at work: toward a theory of personal initiative. In J. Heckhausen (Ed.), Motivational psychology of human development: Developing motivation and motivating development (pp. 307-324). New York: Elsevier Science.

[25] Gagen, L. \& Bowie, S. (2005). Effective mentoring: A case for training mentors for novice teachers. Journal of Physical Education, Recreation \& Dance, 76 (7), 40-45.

[26] Geist, J.R. (2002). Predictors of faculty trust in elementary schools: Enabling bureaucracy, teacher professionalism and academic press. Unpublished doctoral dissertation, The Ohio State University, Ohio.

[27] Gidman, L.K. (2013). Faculty member perceptions of academic leadership styles at private colleges. Unpublished doctoral dissertation, Indiana: Indiana Wesleyan University.

[28] Gill, D.P. (2012). Noncredit and credit divisions in community colleges: the dilemma of multiple organizational identities. Unpublished doctoral dissertation, Boston: University of Massachusetts.

[29] Gmelch, W.H., \& Burns, J.S. (1994). Sources of stress for academic department chairpersons. Journal of Educational Administration, 32 (1), 79-94.

[30] Gmelch, W.H. \& Gates, G.S. (1995, April). The stressful journey of the department chair: An academic in need of a compass and clock. Paper pesented at the annual meeting of the American Educational Research Association, San Francisco, CA.

[31] Gmelch, W.H. (2004). The department chair's balancing acts. In W.H. Gmelch \& J.H. Schuh (Eds.), The Life Cycle of a Department Chair: New directions for higher education (pp. 69-84). New York: Jossey-Bass.

[32] Harris, T.E. \& Nelson, M.D. (2008). Applied organizational communication. New York: Taylor \& Francis. 
[33] Hellawell, D. \& Hancock, N. (2003). Between hierarchical control and collegiality: The academic middle manager in higher education. In N. Bennett, M. Crawford \& $M$. Cartwright (Eds.), Effective educational leadership (pp. 247-264). London: Paul Chapman.

[34] Hobson, A.J., Ashby, P., Malderez, A. \& Tomlinson, P.D. (2009). Mentoring beginning teachers: What we know and what we don't. Teaching and Teacher Education, 25, 207-216.

[35] Hoy, W.K. \& Miskel, C.G. (2010). Eğitim yönetimi (S. Turan, Trans.). Ankara: Nobel. (Original work published 1998)

[36] Kalargyrov, V., Pescosolido, A.T. \& Kalargiros, E.A. (2012). Leadership skills in management education. Academy of Educational Leadership Journal, 16 (4), 39-63.

[37] Kleinbaum, A.M., Stuart, T.E. \& Tushman, M.L. (2008, July). Communication (and coordination?) in a modern, complex organization. Paper presented at the annual meeting of the American Sociological Association, Boston, Harvard Business School.

[38] Korkut, H. (1992). Üniversite akademik yöneticilerinin liderlik davranışları. Amme İdaresi Dergisi, 25 (1), 159-174.

[39] Lee, O.W.K. (2009). The 'innovator's dilemma' and the experience of community college leaders: a phenomenological inquiry. Unpublished doctoral dissertation, Santa Barbara: Fielding Graduate University.

[40] Loughry, M.L. (2010). Peer control in organizations. In S.B.Sitkin, L.B.Cardinal \& K.M.Bijlsma Frankema (Eds.), Organizational control (pp. 324-362). Cambridge: Cambridge University Press.

[41] Lunenburg, F.C. \& Ornstein, A.C. (2000). Educational administration concepts and practices. United States: Wadsworth Thomson Learning.

[42] Maringe, F. \& Foskett, N. (2010). Globalization and internationalization in higher education. New York: Continuum International.

[43] Marjoribanks, K. (1977). Bureaucratic orientations, autonomy and the professional attitudes of teachers. Journal of Educational Administration, 15 (1), 104-113.

[44] Neuendorf, K.A. (2002). The content analysis guidebook. Thousand Oaks: Sage.

\footnotetext{
i This study is adapted from the $\mathrm{PhD}$ dissertation with the same title (in Anadolu University, 2016) which the first author prepared under the supervision of the second author.
}

[45] Ogawa, T.R., Crowson, L.R. \& Goldring, E.B. (1999). Enduring dilemmas of school organization.In J. Murphy \& K.S. Louis (Eds.), Handbook of research on educational administration (pp. 277-296). San-Francisco: Jossey-Bass.

[46] Ölçer, N. \& Koçer, S. (2015). Örgütsel iletişim: Kocaeli Üniversitesi akademik personeli üzerine bir inceleme. Global Media Journal, 6 (11), 339-383.

[47] Sergiovanni, T.J., Burlingame, M., Coombs, F.S. \& Thurston, P.W. (1999). Educational governance and administration. Boston: Allyn \& Bacon.

[48] Simon, H. A. (1996). The proverbs of administration. In J.M. Shafritz \& J.S. Ott (Eds.), Classics of organization theory (pp. 112-126). New York: Harcourt Brace College.

[49] Storey, J. \& Salaman, G. (2009). Managerial dilemmas. West Susex: Wiley Publication.

[50] Şimşek, H. (1997). Metaphorical images of an organization: the power of symbolic constructs in reading change in higher education organizations. Higher Education, 33, 283-307.

[51] Şişman, M. (2010). Türk eğitim sistemi ve okul yönetimi. Ankara: Pegem Akademi.

[52] Taymaz, H. (2009). Okul yönetimi. Ankara: Pegem Akademi.

[53] Walker, A.H. \& Lorsch, J.W. (1996). Organizational choice: Product versus function. In J.M. Shafritz \& J.S. Ott (Eds.), Classics of organization theory (pp. 220- 231). New York: Harcourt Brace College Pub.

[54] Weick, K.E. (1982). Administering education in loosely coupled schools. The Phi Delta Kappan, 63 (10), 673-676.

[55] Wilensky, H.L. (1964). The professionalization of everyone. American Journal of Sociology, 70 (2), 137-158.

[56] Wright, W.A. \& O’Neil, M.C. (1995). Teaching improvement practices: International perspectives. In W.A.Wright (Ed.), Teaching improvement practices: Successful strategies for higher education (pp. 1-57). Bolton, MA: Anker.

[57] Yıldırım, A. \& Şimşek, H. (2008). Sosyal bilimlerde nitel araştırma yöntemleri.Ankara: Seçkin Yayınları.

[58] Zanjani, M.M. (2012). Voices of experience: understanding and enhancing successful conflict management by community college presidents. Unpublished doctoral dissertation, Oregon: Oregon State University. 